\title{
Polyphony and counterpoint: Mechanisms of seduction in the diaries of Helen Hessel and Henri Pierre Roché
}

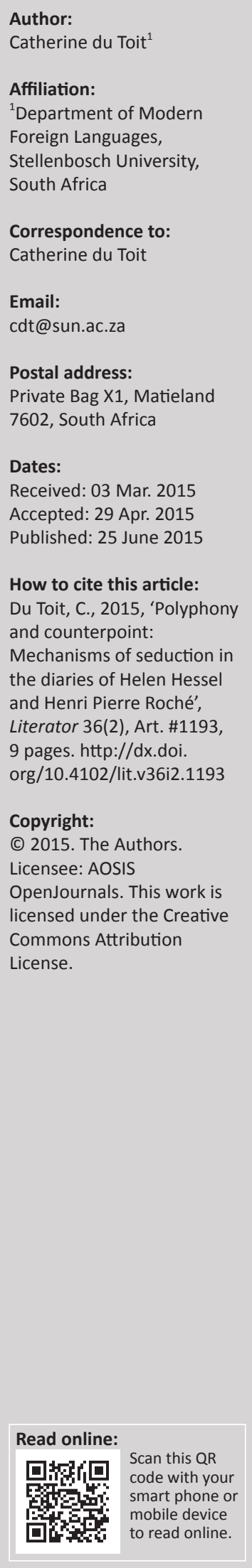

Henri Pierre Roché (1879-1959), the author of Jules et Jim, has been called a general introducer, an exemplary amateur, a collector of women and art and one of the most prolific diarists and active lovers in recorded history. Author of a collection of vignettes about Don Juan, Roché was fascinated with the figure of the seducer and in his twenties planned to devote his life to the creation of a body of work which would examine moral, intellectual, social and sexual relations between women and men. To this end, he would transform his life into a laboratory where real-life experiences would become the main source of reference. Roché's diary spans sixty years and abounds in tales of seduction. However, the most intense and captivating intrigue of seduction and betrayal in his diary, is his relationship with Helen Hessel. At the start of their affair, Roché suggested that she too should keep a diary of the maelstrom of passion into which they were plunged. Written in French, German and English, Helen Hessel's diary captures the drama of seduction and functions on several levels: realistic, visionary, absorbed in her thoughts and emotions and yet critical of herself and others. A juxtaposed reading of the two diaries generates a fascinatingly dense texture, revealing the mechanisms of seduction at play. The counterpoint created by these two interdependent voices becomes ever more complex as one becomes aware of the intertextual references that contribute to the emerging polyphony of recorded life and love.

Polifonie en kontrapunt: Meganismes van verleiding in die dagboeke van Helen Hessel en Henri Pierre Roché. Henri Pierre Roché (1879-1959), outeur van Jules et Jim, word beskryf as 'n sosiale koppelaar, 'n model-liefhebber van alles en nog wat, 'n versamelaar van vroue en kuns en een van die mees produktiewe dagboekskrywers en aktiewe minnaars in die opgetekende geskiedenis. Roché het 'n reeks sketse oor Don Juan gepubliseer en was geboei deur die figuur van die verleier. In sy twintigs beplan hy om sy lewe te wy aan die skepping van 'n œuvre wat die morele, intellektuele, sosiale en seksuele verhoudings tussen mans en vrouens sou ondersoek. Ter bereiking van hierdie doel, rig hy sy lewe in as laboratorium waarin werklike ondervindinge dien as hoofbron van inligting. Sy dagboek strek oor sestig jaar en is ryk aan verhale van verleiding. Desnieteenstaande bly die mees intense en boeiende intrige van verleiding en verraad steeds sy verhouding met Helen Hessel. Aan die begin van hulle verhouding, stel Roché voor dat sy ook 'n dagboek hou van hulle hartstogtelike liefde. Helen Hessel se dagboek, geskryf in Frans, Duits en Engels, reflekteer die drama van verleiding en funksioneer op verskillende vlakke: realisties, visionêr, ten volle geabsorbeer in haar eie gedagtes en emosies en tóg krities jeens haarself en ander. ' $n$ Vergelyking van die twee dagboeke skep ' $n$ fassinerende, digte tekstuur wat die binnewerkings blootlê van verleiding in aksie. Die kontrapunt geskep deur hierdie twee interafhanklike stemme word nóg meer kompleks namate ' $n$ mens bewus word van die intertekstuele verwysings wat bydra tot die ontluikende polifonie van geskrewe liefde en lewe.

[...] je relis tout ce que j'ai écrit depuis trois semaines. Je trouve pour moi intéressant la vie même, avec ses fluctuations d'amour et de haine, ou de froideur et de volonté de rupture - qui sont l'amour. J'y sens la montée, le crescendo de notre amour. ${ }^{1}$ (Roché 1990)

When Henri Pierre Roché and Helen Hessel met in August 1920, several factors converged to transform their resulting affair into a modern myth of love. But neither the novel Jules et Jim nor François Truffaut's New Wave masterpiece quite captures the subtleties of the seduction that wove such a twisted tale of love and passion. A juxtaposed reading of their respective diaries generates a fascinating polyphony, plunging the reader, as a vicarious participant in the unfolding of events, into the dynamic core of love.

1.1 reread everything I have written these past three weeks. I find life itself interesting, with its ebb and flow of love and hatred or of indifference and the desire to break up that constitute love. In this I feel the surge, the crescendo of our love.' (All translations from the diaries of Henri Pierre Roché and Helen Hessel are by the author.) 
The dense polyphonic texture of this narrative stems not only from the diaries of Roché and Helen Hessel but also from the various literary and philosophical references that are either explicitly or implicitly present in their writing. Within the diverging and converging movement of these distinct diary fragments, accompanied by allusions and intertextual references, a dynamic image emerges of the birth and death of love. Initial desire and seduction are fuelled by constant regeneration in the act of daily writing, writing that contributes to the transfiguration of the world as it creates a new and palpable reality whilst preserving emotions and passions which would otherwise decay and dissolve. The fragments of a diary are not impartial. They possess their own agency as constituents of an individual life and the way in which this individual chooses to make sense of his life but without the relative certainty awarded by hindsight as is the case with autobiography. Even so, complete transparency remains an illusion that can only feed an illusory desire when the diary is intended to serve as a tool to fan the flames of passion. As Georges Gusdorf (1991) explains in Les Écritures du moi:

Entre le moi vécu et l'écriture du moi selon l'ordre de l'écriture, se réalise une transsubstantiation, ou plutôt une dénaturation si le moi veut se dire en forme de discours $[\ldots]^{\prime 2}$ (p. 336)

Intertextual references can, to a certain extent, help to fill the disconcerting and deceptive gaps left by the fragmented narrative of the two parallel diaries. By combining various lines of narrative, like melody lines in a contrapuntal composition, we distinguish the contours of love, following its irrepressible eruption and imagining its destruction. For the end of love, le désamour, reveals the force of passion in the energy required for its obliteration. In Jules et Jim, the novel Henri Pierre Roché would eventually write about his relationship with Helen Hessel, this devastating erasure of love could only be projected in the death of their literary alter egos.

Born in 1879, Henri Pierre Roché decides as early as 1902 that his life should be devoted to the study of the relationship between man and woman. 'J'étudierai les relations morales, intellectuelles, sociales et sexuelles de l'Homme et de la Femme $^{\prime 3}$ (Journal: 15 August 1902). In this vast programme sexuality rapidly emerges as the linchpin that will define all other relationships. His main reference will be himself, his life and experiences. He accepts that this might entail a sacrifice '[...] renonciation au bonheur - renonciation à une vie pour connaître beaucoup de vies' ${ }^{4}$ (Journal: 04 October 1902). He, therefore, anticipates having to live several lives, parallel lives that would allow him to multiply experiences. This project, initially referred to as 'la polygamie expérimentale' would soon become a way of life. The documentation of his experiences starts out in an orderly, pseudo-scientific

\footnotetext{
2."'Between the self that lives and the writing of the self according to the principles of writing, there is a transsubstantiation or rather a denaturation if the self wants to reflect itself in discourse."'

3.'I shall study the moral, intellectual, social and sexual relations between Man and Woman.'

4.'[...] Renouncing happiness - renouncing one life to know many lives.'
}

fashion. After placing a matrimonial advertisement, he carefully selects correspondents and exchanges a few letters before suggesting a meeting. Details of the meetings are then documented on cards, in A6 format. Soon enough, life and project merge inextricably and Roché's diary takes over the function of documentation. In her 1911 word portrait of Roché, Gertrude Stein (1922] 2003) describes him as follows:

This one is one certainly loving, doing a great deal of loving, certainly this one has been completely excited by such a thing, certainly this one had been completely dreaming about such a thing. Certainly this one is one who would be very pleasant to very many in loving. (p. 142)

In 1906, Roché makes the acquaintance of Franz Hessel, a German Jewish author who had recently joined the bustling gathering of writers and artists in Montparnasse. A firm friendship blossoms and they rapidly form an inseparable couple. Their friendship is such that it gradually disaffects them from their former circles, soon enough leading to rumours about the nature of their relationship. They work together and travel together - to Germany, Italy and Greece. At Chalcis, they find the 'archaic smile' of their ideal woman in a sculpture of a young girl being carried off by a satyr and they resolve to find this smile in the flesh. The intimacy of their friendship is reinforced by their conversations on love and lovers and they soon find themselves loving the same women: Marie Laurencin, Franziska zu Reventlow, Luise Bücking, Euphemia Lamb, to name but a few. Most often Roché ends up enticing favours away from Hessel. In the autumn of 1912, Hessel meets a young German girl at the Café du Dôme. Helen Grund is studying painting under Maurice Denis and provides a living embodiment of the archaic smile. Hessel falls deeply in love with her and begs Roché not to court Helen. 'Pierre, pas Helen, je vous prie, pas celle-là' ${ }^{5}$ (Diary 1920 'Luk à Paris en 1913'. This request creates a firewall between Roché and Helen. In her diary, she would later recall of their first meetings: 'J'ai quelquefois vu Pierre, c'était toujours un émoi - mais il semblait nous protéger, Franz et moi - et c'est son amitié pour Franz qui le fait s'intéresser à moi' ${ }^{6}$ (Hessel 1991:436). In June 1913, Helen and Franz get married. They move to Germany shortly before the First World War begins.

Several factors set the stage for the start of Roché and Helen's affair in 1920, most importantly, the notion of seduction as embodied in the literary myth of Don Juan, the notion of procreation and Roché's conception of 'elective affinities'. The figure of the seducer had always fascinated Roché. In 1920 he revises the final draft of his collection of sketches, published towards the end of the year under the title Don Juan et... Visiting the Hessels, Roché on several occasions reads from his Don Juan, they discuss the stories and the characters and Franz starts working on a German translation of the text. It is clear from the outset that Helen not only identifies Roché with his Don Juan character but that she also sees herself in

5.'Pierre, not Helen, ibeg nou, not this one.

6.I sometimes saw Pierre, it was always a moving experience - but he seemed to protect Franz and me - and it was because of his friendship with Franz that I interested him.' 
the figure of the seducer. As most of the sketches have an autobiographical dimension, it is not surprising that she maintains: 'Je n'ai pas d'imagination. J'imagine [Don Juan] comme Pierre, comme l'auteur. Tout à fait ${ }^{7}$ (Hessel 1991:28). Strikingly, she sees herself increasingly as Don Juan, or even as the author: 'Si j'étais homme, je serais lui. Peut-être meilleur' ${ }^{8}$ (92); 'J'aime vraiment beaucoup “Don Juan". J'ai l'impression de l'avoir écrit, pendant que j'étais un homme ${ }^{\prime 9}$ (p. 543).

As she becomes progressively more involved with Roché's book, Helen expresses her opinion that it needs a female voice in counterpoint. 'Don Juan me fait envie d'écrire “Dona Juana"'10 (p. 454). Roché asks her to write a preface for the German translation of Don Juan et... It is clear that Helen understands the Don Juan figure in terms of Roché's (1990) own seductive mechanisms:

Faible - féminin. Attirant justement à cause de ça. Sa voix douce, son sommeil léger. Son 'Don Juan'? Il est grand artiste. Il a la force de se mettre à l'extérieur de lui-même, de se recréer, de former ${ }^{11}$ (p. 344)

In order to seduce, one must know and understand the objects of seduction, work oneself under their skin, fashion a heart in their image, as Kierkegaard (1993:330) puts it in his Diary of a seducer. For Don Juan, this would signify abdicating his own sex and his virility to become a woman for an instant. But does this not mean that Don Juan ultimately seduces only his illusion of a woman through an illusion of himself? For Frédéric Monneyron (1991:165), this is the paradox inherent in the western notion of seduction: seduction is only ever the seduction of an illusion which is in itself the illusion of seduction. In this sense, the seducer is the first to be led astray, to become the first victim of seduction.

Roché's Don Juan lies within the scope of the early 20th century treatment of the seducer. He is far from being the 'grand seigneur méchant homme' ('great lord and evil man') of the classical tradition as portrayed in, for example, Molière's Dom Juan ou le Festin de Pierre of 1682. Frequently ridiculed, the modern Don Juan is often uncertain, weak, tired and deceived, a rather mediocre and slightly bitter figure. Nonetheless, the notion of desire remains central to his character. He desires to see the transformation his seduction inspires in the eyes of his victims. That the power of his seduction should have the capacity of transforming the existence and the destiny of another being, intoxicates him. But, of course, the intoxicating moment only occurs once and Don Juan must then abandon his victim in order to find the same ecstasy elsewhere. The resulting fragmentation

7.!I have no imagination. I imagine [Don Juan] like Pierre, like the author. Absolutely.' 8.'If I were a man, I would be him. Perhaps better.'

9.I really like 'Don Juan'. I have the impression that I wrote it myself when I was a man.'

10.'Don Juan makes me want to write "Dona Juana"'

11.'Weak - feminine. Attractive precisely because of this. His soft voice, his light sleep. His 'Don Juan'? He is a great artist. He has the capacity to place himself outside of himself, to recreate himself, to form himself.' that forms an essential part of the typical Don Juan figure is exaggerated in Roché's portrayal. His Don Juan suffers from a lack of internal cohesion, forming the basis for the irony in which the character is steeped. This irony is not, however, without pathos, as Don Juan's destiny perpetually leads to division and disunity. In Roché's text, Don Juan considers it a duty and at times even a penance to seduce the women he encounters. Consequently, the force of seduction is undermined by the notion of desire as a personal vocation and a social obligation. The element of transgression, essential to erotic desire, is weakened and even disappears as the female objects of desire are such consenting and even eager victims. Inevitably, Don Juan himself becomes a victim of his own desire and that of the women who surround him. Unlike the classical Don Juan, he does not rebel against a divine force, but against his own condition of a seducer for whom lightness and dispersion have become an unbearable burden.

The figure of Don Juan both foreshadows and permeates Roché and Helen Hessel's relationship in more than just its literary manifestation. Helen considers Roché's reputation as a seducer a challenge and seems to find in him an ideal and equal sparring partner. She flirts, flaunts her conquests and exaggerates her amorous exploits in order to match his. Throughout the first months of their affair she openly undertakes to seduce another of Hessel's friends, the archaeologist, Hubert Koch - apparently without intending anything more than an open-ended display of her seductive powers. Wanting to conform to her projection of the female Don Juan figure, she is even concerned that Roché will not find her a strong enough partner if she does not push her behaviour to the limit. 'Pierre s'inquiètera. Très bien. Il trouvera médiocre que nous n'ayons pas fait l'amour, Koch et moi $^{12}$ (Hessel 1991:151). Thus, the image of Don Juan as a model of seduction plays an important role in moulding Roché and Helen's initial attraction to one another and sets the tone for their future relationship.

Alongside the scene set by the figure of the seducer, another seemingly contradictory factor prefigures Roché and Helen Hessel's meeting: the notion of procreation. The logical framework of the Don Juan myth prohibits the seducer from being a father. Even so, Don Juan has had fatherhood thrust upon him by several authors, starting with Nikolaus Lenau in 1842. And fatherhood is the adventure that tempts Roché in the summer of 1920. Making his way through Germany, his diary abounds in reflections on procreation and parenthood. He has read and admired Maria Montessori's books on early childhood education, he describes the women he meets in terms of their childbearing qualities and he reflects upon his own 'modesty' with regards to reproduction (Roché 1990:6). When he meets Helen for the first time, he describes her as 'all mother' (p. 30) and their first outing together is to a circus with Helen's two young boys where they visit one of the caravans to see a new-born baby. Even though Franz Hessel's

12.'Pierre will be worried. Very well. He will find it mediocre that we didn't make love, Koch and I.' 
only request at the start of the affair is that Roché and Helen should avoid having a child together, Roché would almost immediately tell Helen that he sees her as the ideal mother for a child of his. Her strength would compensate for all his weaknesses. Helen seizes this image and adds it to her array of seduction tools. 'En le regardant, soudaine lumière, bonheur. Décision nette - je le prendrai pour moi. [...] J'ai l'idée d'être une mère, de sembler mère ${ }^{\prime 13}$ (Hessel 1991:29). Everything indicates that motherhood is indeed an important part of Helen's identity. But intentionally cultivating an image of herself as a natural, inspired earth mother also becomes a way of impressing her uniqueness and irreplaceability on Roché. Roché (1990), for his part, encourages this reaction by imagining a son who would be the fruit of their love:

C'est Hln. à l'âme violente mais plus large, plus en dehors de la société, plus géniale, plus risquante, plus toute nue et héroïque, et me comprenant, et m'attendant, et disposant d'une force immense et divine, et pouvant épouser ma direction et $\mathrm{m}^{\prime}$ inoculer la sienne, $c^{\prime}$ est Hln. qui fera mon fils ${ }^{14}$ (p. 92)

Throughout the 13 years that their relationship would last, this fiction of the son would play a central role in all their major upheavals.

'Sensuality often makes love grow too quickly, so that the root remains weak and is easy to pull out', according to a Nietzschean ([1886] 1973:80) aphorism in Beyond good and evil. Overwhelmed by the very rapid development of their relationship - in a given seductive context where strategy seemed superfluous - Helen and Roché are forced, in the aftermath of their first physical contact, to resort to a fervent campaign of mutual seduction to maintain the level of erotic tension. The result is a continuous game where seducer and seduced incessantly change places, making use of the same or of individualized mechanisms of seduction.

Destabilizing and disorientating one another forms part of both Helen and Roché's seduction technique. Creating everunexpected diversions and avoiding predictability serve to maintain a lively interest, to keep the lines of tension taut. A mutual taste for transgression serves the same purpose, whether this involves lovemaking in public or creating the fantasy of sharing a criminal secret. Finally, both are adept at playing with their gender. This creates a sense of ambiguity, confusion and excitement. Helen frequently imagines how she would act as a man. She also dresses up in men's clothes and engages Roché in role playing. Taking part in a Freudian question and answer game Roché admits that he would like to be a woman for a while. 'He would be me', Helen thinks (Hessel 1991:19).

Roché, in his attitude towards women, cultivates a caring approach, not dazzling his conquests by a flood of flattering

13.'Looking at him, a sudden light, happiness. A clear decision - I will take him for myself. [...] I have the idea of being a mother, of appearing to be a mother.'

14.'It is HIn. with her violent but larger soul, more marginal to society, more genial, more daring, more utterly naked and heroic and understanding me and waiting for me and possessing an immense and divine force and adopting my direction and filling me with hers, it is Hln. who will give me a son.' words, but rather listening attentively and earnestly, making each woman the centre of his attention, thus validating her self-esteem. One of his literary mistresses, the Countess Franziska zu Reventlow (Reventlow [1912] 1969), sums up his attitude in her autobiographical novel Amouresken. Von Paul zu Pedro:

Er hat sehr vielfältige Beziehungen zu Frauen und kultiviert jede einzelne wie ein Gärtner seine Pflanzen, jede bekommt ihre besonderes Terrain und ihre besondere Pflege. Für jede ist er der aufmerksamste und angenehmste Galant und suggeriert durchaus das Gefühl, daß er im Moment nur für sie da ist' ${ }^{15}$ (s.p.)

Roché himself is very aware of the attraction his devoted selflessness exercises and ascribes it to his own curiosity. He opens himself to the presence of each woman because he sincerely wants to understand what moves her in love. $\mathrm{He}$, therefore, allows them to talk, adapting to their moods and needs, and encourages them to reveal themselves. This technique has the added advantage that it seemingly places the woman in a position of power, creating the illusion that the seducer is being seduced:

Pourquoi les femmes viennent-elles à moi? Parce que je suis toujours disponible. Parce que mes yeux de spectateur sont prêts à rendre les hommages dus, parce que je suis prêt à me laisser manger jusqu'à un certain point par toute femme de mérite ${ }^{16}$ (Journal: 27 July 1922; Roché 1990)

Knowing his targets, with all their insecurities and their need to be understood, is also essential to another of Rochés seductive ploys. After listening to a woman for a while, flattering her sense of worth and making her the focus of his attention, he will lash out and criticise her. Because he knows her intimately, the accusations may well cut to the bone. This confuses the victim, suddenly making her feel fragile and inadequate and ultimately dependent on Roché to restore her self-worth. The following quote from his 1905 diary shows how calculatingly Roché made use of this mechanism:

Je l'attaque, je lui fais soudain des critiques, sur elle, sur les points faibles où elle doute d'elle. Elle réfléchit intensément. Elle est déséquilibrée, c'est son charme. La voilà en déroute. Maintenant je la calme, je parle avec conviction contre son grand doute d'elle-même qui la rend folle, je mets sous sa main mon désir et mon admiration. Elle me regarde, vient se serrer contre moi, dit: 'Je ne vous ai jamais tant aimé ${ }^{17}$ (Journal: 21 April 1905; Roché 1990)

With Helen, he applies the same technique with similar results. She is accustomed to being surrounded by a circle

\footnotetext{
15. He had very many relationships with women and cultivated each like a gardener his plants; each had her own soil and her special treatment. For each he was the most attentive and pleasant gentleman and throughout suggested the feeling that at that moment he was there only for her.' (Author's translation.)

16.'Why do women come to me? Because I am always available. Because my spectator's eyes are ready to pay them the homage they deserve, because I am ready to be eaten to a certain point by any woman of merit.'

17.'I attack her, I suddenly criticize her, her weak points where she doubts herself. She T attack her, I suddenly criticize her, her weak points where she doubts herself. She her and speak with conviction against the self-doubt that makes her insane, I lay bare all my desire and my admiration. She looks at me, presses against me, says: "I have never loved you so."”
} 
of unconditional admirers. Roché's attacks catch her unawares, jolting her out of her usual sense of normality (Greene 2001:206) and making him appear as a masterful hero:

Je suis comme aveuglée par ce coup inattendu. Et offensée et triste. C'est dur - et cruel - et vrai. [...] Je souffre comme si Pierre avait mis son poing son ma nuque et m'avait pliée en avant. [...] $\mathrm{Au}$ lit avec Pierre. Mon maître. C'est beau qu'il exige ${ }^{18}$ (Hessel 1991:325-326)

Helen finds seducing and being seduced equally seductive. But both lead to an increased absorption with her own image. Images of reflexivity fill her diary. Looking at herself through the imagined eyes of Pierre, she becomes obsessed with her appearance. She imagines how he would perceive her, and who she would be for him: 'Il me regarde. Je suis douloureusement consciente de ma laideur. Sentiment de faute et de fraude. Effort de me rappeler que ça n'empêche pas $1^{\prime}$ amour $^{19}$ (p. 42). The lack of authenticity that characterizes the seducer who enters into his victim's spirit, also affects the seduced whose self comes to be shaped by another's will or expectations. Neither the seducer nor the seduced asks 'Who are you?' but rather 'Who should I be?' In the midst of this inauthenticity, Helen's sense of self vacillates:

Qui donc a plus de force que mon désir? Qu'est-ce qui me force à m'éloigner de moi-même, à sortir de mon attitude naturelle ? $C^{\prime}$ est comme si mes yeux regardaient derrière ma tête - ça fait mal $^{20}$ (Roché 1990:330)

This fluctuation plays a part in a technique of seduction characteristic of Helen: she adopts different personae in rapid succession - the flirt, the mother, the tomboy, the modern intellectual, the farm worker - surrounding those she wants to seduce with mystery, with an altered sense of time and space. Her role playing often takes the form of an uninterrupted carnivalesque atmosphere where she controls the suggestions and impressions with calculated effect. Roché calls her 'une metteuse en scène incomparable ${ }^{21}$ (Roché 'Diary'22 1920: 17 August).

Roché's conception of sexual affinity and desire is informed by various literary and philosophical texts in French, English and German. One of the texts that features largely and over a long period in his thinking about sexuality is Geschlecht und Charakter (translated as Sex and character in 1906) by the young Viennese philosopher, Otto Weininger, to which he was introduced by Leo Stein in 1907.

18.1 am as if blinded by this unexpected blow. And offended and sad. It is hard - and cruel - and true. [...] I suffer as though Pierre had placed his fist against my neck and had bent me forward [...] In bed with Pierre. My master. I like it that he is demanding.'

19.'He looks at me. I am painfully aware of my ugliness. A feeling of error and fraud. An effort to remember that this does not prevent love.'

20.'Who then has more power than my desire? What forces me from myself, leaving my natural pose? It is as if my eyes were watching from the back of my head - it hurts.'

21.'an incomparable stage director'

22.In 1920, Roché starts a separate expanded account of his affair with Helen Hessel, which he calls 'Dairy'.
A male individual $m$ may be composed as follows:

$$
m \mid \begin{gathered}
3 / 4 \mathrm{M} \\
\text { and } \\
1 / 4 \mathrm{~F}
\end{gathered}
$$

his best sexual complement will, according to this law, be an individual $f$, defined as:

$$
\begin{array}{l|l}
\mathrm{f} & 3 / 4 \mathrm{M} \\
\text { and } \\
1 / 4 \mathrm{~F}
\end{array}
$$

FIGURE 1: Sexual affinity, according to Otto Weininger.

\begin{tabular}{|ll|}
\hline & \\
$A=\frac{k}{a-b} \cdot f(t)$ & $\begin{array}{l}\mathrm{b}=\text { value of the masculine principle } \\
\mathrm{A}=\text { force of attraction } \\
\mathrm{f}(\mathrm{t})=\text { reaction time } \\
\mathrm{k}=\text { proportional representation comprising "all the } \\
\text { known and unknown laws of sexual affinity" (48). }\end{array}$ \\
\hline
\end{tabular}

FIGURE 2: Otto Weininger's formula of sexual attraction.

Geschlecht und Charakter is the extension of Weininger's doctoral thesis in philosophy. ${ }^{23}$ The premise of the thesis is the notion of universal bisexuality; in other words, no human being is entirely male or female but contains both masculine and feminine components. These components are considered as both contrary and complementary. Together, they form a complete individual, but no actual person contains such a fusion of characteristics as to be considered complete. This individual constitution of man and woman is a determining factor in the laws of attraction established by Weininger (1975), with the help of serious looking calculations:

To calculate the sexual affinity between two individuals, he also takes into account other factors, including the degree of affinity according to type, race, family, health and relative absence of physical faults, as well as the time during which the two individuals are exposed to and act upon each other. (p. 42)

In the central part of the work, the masculine and feminine principles are explained. The male principle possesses an unlimited and unconditional intelligence, conceptual reason and a sense of identity, whereas the female principle is nonconceptual, and conderns matter rather than form, submits to impressions and sensations, and has no identity of its own. Weininger illustrates these principles by referring to the prominent artistic movement of the time as eminently feminine. 'Masculine reason is fundamentally different from feminine reason through the need it has of certain forms and this "impressionist" art is always and per definition an "art" without form' (Weininger 1975:161). The masculine and feminine principles should complete one another. Without

23. Selective and uncontextualised readings of Weininger's work have branded both author and text as misogynist, anti-semitic and generally anathema to feminists feminists and the ideologically sensitive. Such readings, however, do not take into account the historical and social context of Weininger's work, nor the Caricent infuence he had on early enlightened sexologists, such as Edward Carpenter, for whom the relationship between sexual and social change was an essential issue. 
form, matter is only disorder, but without matter, form remains only an idea. This is how one should understand Weininger when he writes: 'The absolute woman has no self' (Weininger 1975:158). The masculine principle contains a divisive, antiauthoritarian and dynamic character. The feminine principle is driven by the instinct to merge, expressed in its passive, continuous, integrating and protective character. This is why the essence of femininity is ' pimping', ${ }^{24}$ the profound desire to see others coupling, as 'it identifies with universal sexuality. Coupling represents a supreme value for a woman and she constantly seeks to see it realized' (Weininger 1975:214). Universal sexuality is focused on the continuation of the species, the absorption of the individual into the perennity of a community, whence the idea that a woman is 'in her entire personality, physically as well as mentally, only sexual and sexuality itself' (Weininger 1975:214).

The masculine principle imposes a conscious and individual form on the pure sexuality of the feminine principle. The very nature of the feminine principle riles against this limitation. This is where woman becomes a mere object created by man's desire, 'an objectification of masculine sexuality' (Weininger 1975:244):

Sex, as it is incarnated in man, represents the destiny and the fate of woman; Don Juan is the only human type in front of which woman trembles in the very quick of her being (Weininger 1975:243)

For woman to liberate herself from man, from the right he assumes to impose his own form upon her, she must renounce the feminine principle's inclination to sexuality, in other words, negate the feminine principle in herself, as 'sex is the ransom man pays woman in order that she will continue to submit to him' (Weininger 1975:277). Finally, in the last chapter, that deals with woman and mankind, Weininger (1975) maintains that the problems of mankind will not be resolved as long as the problems of woman persist:

Man must try to see the idea in woman, the noumenon, and not use her as a means to an end beyond herself. He must recognize that she has the same rights and therewith the same duties (of moral culture and spirituality) as himself. He will not be able to resolve his own moral problems as long as he negates the idea of humanity in woman, in other words, as long as he turns her into an instrument of pleasure. (p. 277)

One readily understands why this dense and multi-faceted book holds such a fascination for Roché, who judges its influence on his conception of desire and eroticism to be greater than that of Stendhal's seminal work on love, De l'Amour (Journal: 21 August 1921). Weininger displays a naturalist's approach, which shows a similar curiosity to that which drives Roché's early 'experimental polygamy' project. In both cases, the propelling force is a search for absolute principles that are conceived of as an almost divine vocation. It is the duty of an exceptional being to elucidate the

24.'Kuppelei' in the German original text, 'maquerellage' in French and 'match making' in the first English edition; 'pimping' is a more accurate translation of the original German verb. mysteries of life. The idea of the 'genius' in Weininger's work is also found in Roché's writings, most often in the shape of the 'artist'. The genius, according to Weininger, understands humanity without having to learn. He knows because he is complex and multiple and holds within himself a knowledge and an understanding of different beings without, however, sacrificing the cohesion of his own self. In order to recognize and to understand that which lies beyond yourself, you must have these elements ready within you. What you understand depends on what you are - on condition that you be more than what you are. The true genius is, therefore, endowed with a human curiosity that allows him to combine several types of human beings in himself. One senses the influence of Nietzsche in this regard in spite of Weininger's refutation. The point of departure for this human knowledge is, for example, as in Nietzsche, a solid self. 'Nur aus sich selbst kann der Mensch die Tiefe der Welt erkennen, in ihm liegen die Zusammenhänge der Welt ${ }^{25}$ (Weininger 1904). Weininger and Roché have the same ultimate objective: the desire to penetrate the mystery of love, to analyse and codify it. The concept of elective affinity plays an important part in this. ${ }^{26}$ Whereas Weininger takes the notion of universal bisexuality as a point of departure, Roché attempts to define the laws of attraction through a classification of types and physical complementarity. The idea of sexual polarity is central to both Weininger and Roché's thinking and Roché finds Weininger's definitions instructive for himself and for the women to whom he recommends Weininger: 'I recommend that she read Sexe et Caractère by Weininger, for male and female character and the principle of identity' (Journal: 18 March 1923). Roché uses Sex and character to support his own observations: 'Je me rappelle avec satisfaction le chapitre où Weininger dit que, tout au fond, la Mère et la Prostituée se valent $^{27}$ (Journal: 21 May 1923).

At the start of his love affair with Helen Hessel, Roché rereads Sex and character and rediscovers its significance. He often refers to it when he analyses their relationship:

Si elles sont un peu hommes par leur force, suis-je, moi, selon la règle de Weininger, un peu femme, si je suis leur complément? Difficile à juger moi-même. J'ai la direction, elles ont la force motrice, comme le formulait une fois $\mathrm{Luk}^{28}$ (Journal: 10 February 1921)

Assez vite après [avoir battu Helen] nous découvrîmes en secret, séparément, que nous avions trouvé une nouvelle façon de faire

25.Man can know the depth of the world only from within himself; in him lies the coherence of the world.

26.This expression inevitably evokes the eponymous novel published by Goethe in 1809 on the force and subtleties of passion. The expression could be seen as an oxymoron as 'affinity' indicates an irrepressible attraction whereas 'elective' contains a notion of conscious selection. In chemistry, 'Elective affinity' denotes the measurable force which keeps atoms together in a compound. The intended ambiguity lends itself perfectly to the pseudo-scientific philosophical theories of Weininger. From the references in his Journal, we know of Roché's admiration for Goethe. Amongst other works, he refers explicitly to the Affinités électives (a theme taken up by Truffaut in the film version of Jules et Jim where Jules asks Jim for the copy of the book as Catherine wants to read it).

27.'With some satisfaction, I recall the chapter in which Weininger explains that there is hardly any difference between the Mother and the Prostitute'.

28.'If they are a little male because of their strength, does it mean that I, according to Weininger's rules, am a little female if I complement them? It is difficult to judge this myself. I have direction, they have the driving force, as Luk once described it: (Luk is a pet name given to Helen by her husband, Franz Hessel.) 
l'amour dont l'âpre volupté m'effraya, et dont je vis clairement qu'elle menait au meurtre: à chaque crise, il faudrait frapper davantage, sous peine d'aimer moins. Je me rappelai cette opinion de Weininger que pour une femme du type prostituée, le plus grand triomphe et le plus grand bonheur est d'être tuée par amour. Je me rappelai la passion ave laquelle Luk nous lisait cet acte du drame de Wedekind où Loulou est tuée par Jacques l'éventreur ${ }^{29}$ (Journal: 22 June 1922)

Apart from these references to Weininger, this second quote shows the intermingling of desire and love in the relationship between Roché and Helen Hessel. Roché often mentions books or reading sessions in his Journal, thereby creating a mise-en-abyme. Here, for example, Helen's identity is tripled by the direct association with two literary figures - the prostitute (both tart and hetaera) from Weininger and Lulu, the femme fatale and natural woman from Frank Wedekind's two plays, Erdgeist (1895) and Die Büchse der Pandora (1903). Lulu is one of the literary figures Weininger uses as a model in Sex and character, which adds to the effect of the mise-en-abyme. But the abyme becomes truly dizzying when one recalls that the model for Lulu was most likely Franziska zu Reventlow, Schwabing's barefoot countess, who was both Henri Pierre Roché and Franz Hessel's lover.

Open exchanges about sexology and eroticism characterize the relationship between Roché and Helen and sustain the erotic tension and mutual fascination ${ }^{30}$. Helen decides on her own to read Weininger after having read Hans Blüher's treatise, Die Rolle der Erotik in der männlichen Gesellschaft (The Role of Eroticism in Male Society) which refers to Sex and character. 'C'était une sorte de révélation - il me semble que je vois un chemin, je t'en parlerai' (Letter from Helen Hessel to HP Roché, 15 August 1921). ${ }^{31}$ When they are apart, it is clear that thinking and writing about eroticism (or writing erotically, in the case of Helen whose intense sexual exaltation is clearly visible in the vicissitudes of her handwriting) doubles as eroticism and fulfils the burning desire of their nascent passion. (See Figure 3.) Shared reading about the nature of sexuality, thus becomes a springboard for their explicit pioneering venture to probe and overstep the boundaries of monogamous morality. Helen, however, does not approve of Weininger in all respects, according to a brief entry in Roché's diary, and at times he prompts her to rail against all men.

Even though Roché does not approve of Weininger's work unreservedly either, his writings abound in examples of possible or evident Weininger influences. Conversely, a

29.Soon after [having beaten Helen] we secretly discovered, each on our own, that we have found a new way of making love, of which the acrid sensuality frightened me and I clearly saw that it would lead to murder: at each point of crisis, I would have to hit harder so as not to love less. I remember this opinion of Weininger that for a woman of the prostitute type, there is no greater triumph or happiness than to be killed by love. I remember the passion with which Luk read us this scene from Wedekind's play where Lulu is killed by Jack the Ripper'

30.'Fascination' is an operative word when it comes to the importance given to Roché's genitals in exchanges between the two lovers. His penis is invariably referred to as 'le God' and one bears in mind that the fascinum or fascinus in ancient Roman religion was the embodiment of the sacred phallus.

31.'It was a kind of revelation - I think I see a way for us, I'Il explain.'

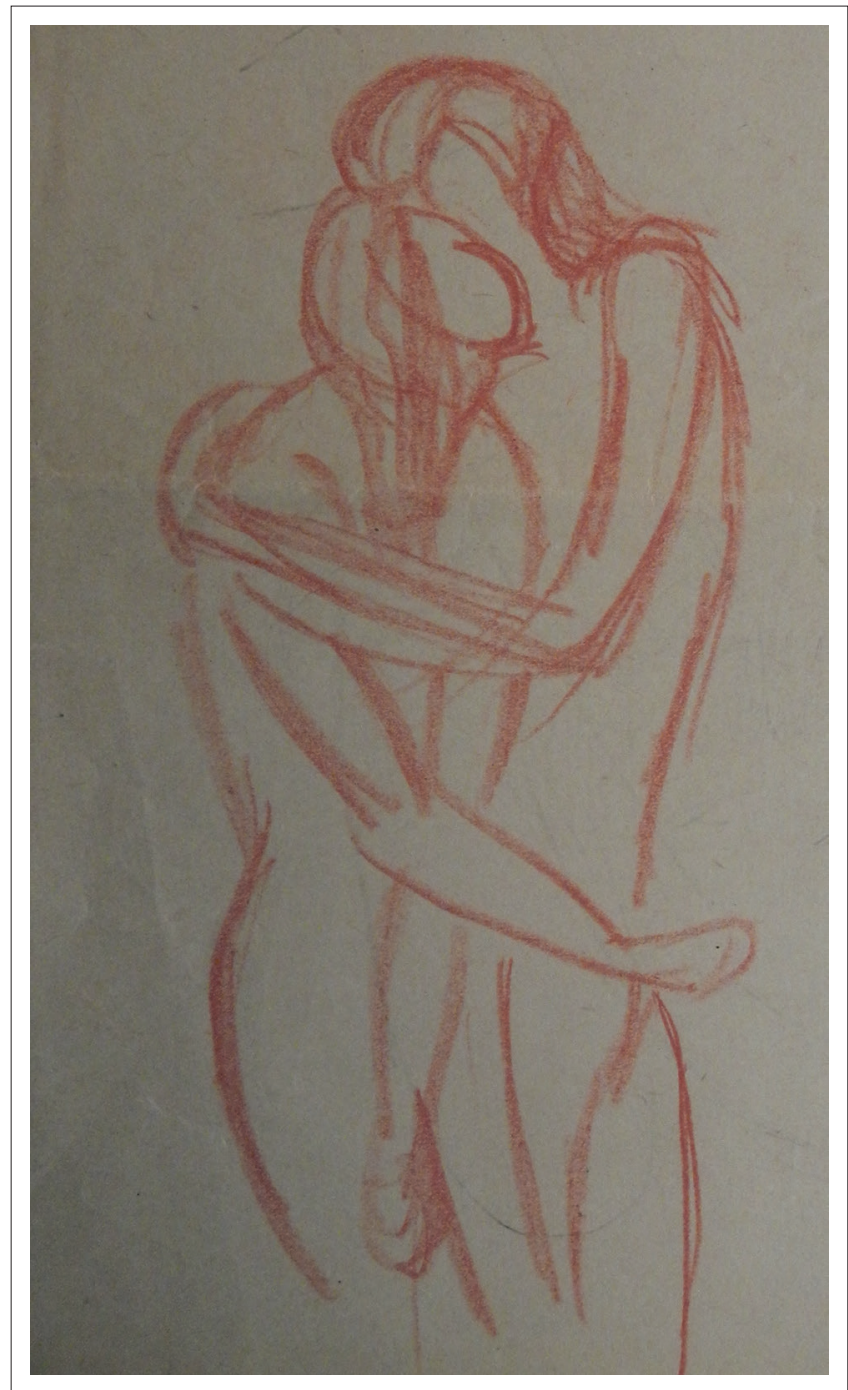

Source: Hessel, H., 1991, Journal d'Helen, André Dimanche, Marseille. [The original copy of Helen Hessel's diary is conserved at the Harry Ransom Centre at the University of Texas at Austin and was consulted with the kind authorization of her son, Stéphane Hessel.]

FIGURE 3: Drawing by Helen Hessel of Pierre Roché and herself.

knowledge of Weininger's principal theories serves to clarify certain recurrent themes in Roché's writings. Infidelity, for example, if interpreted in the context of the laws of attraction and elective affinities, cannot simply be reduced to an evil lie, moral blindness, contempt for others, simple weakness or rampant lust.

Given a union that has taken place between two individuals who, according to my formula, are not adapted to each other. If, at a later stage, the natural complement of either should appear, the inclination to desert this prior but second best union will at once assert itself in accordance with an inevitable law of nature. This is infidelity, a purely natural phenomenon, as when, if iron sulphate and caustic potash are brought together, the $\mathrm{SO} 4$ ions leave the iron to unite with the potassium. When in nature an adjustment of such differences of potential is about to take place, he who would approve or disapprove of the process from a moral point of view would appear to most to play a ridiculous part. (Weininger 1975:51)

More or less three months after the start of their affair and shortly before his return to France, Roché suggests that 
Helen should write a retrospective 'diary' of their meeting to form a feminine counterpart to his own diary. Helen's diary consists of 25 exercise books, capturing all the drama of the different stages of seduction. It is clear, however, that she writes it for a privileged reader, as she sends Roché each notebook as she finishes it. In this sense, and because it seeks to recreate the thrill of nascent passion, the diary itself becomes a tool of seduction. Through writing and re-reading the first moments of passion are re-experienced so vividly that the erotic tension is never quite resolved; this in spite of the fact that writing may also hold a danger for the attempt at perpetual seduction. It creates a finished and complete record of something that should remain open-ended and beyond comprehension. Helen senses this danger:

Si je forme de ces dates une sorte d'œuvre - notre amour vu dans le passé le mettra en dehors de moi - touchable visible - complet - fini - je me tournerai pour faire autre chose ${ }^{32}$ (Hessel 1991:425)

Fearing that the experience itself will be killed by her writing about it, she transforms the writing itself into an experience.

How can seduction be cast in written form? The commentarius perpetuus of the diary furnishes an exemplary framework for the uncoiling of amorous exploits that are, by their nature, punctuated by the daily progress made by the seducer. But this is not all that is at stake. How does one approach that which has happened, how does one capture the extraordinary through the use of forms that serve to establish regularities? How can one relate hidden secrets or that which confounds the heart in known or recognizable representations? Transforming reallife experiences into a narrative does not imply enquiries such as: how to tell the truth, or how to move from the disorder of emotions and feelings to verbal structures. The pertinent question is rather more complex: how, in narrative form, does one not only summarize or organise a sense of existence, but more importantly, provoke it. This works by not only preserving and presenting as precisely as possible the time and unity of the 'lost' experience but by constructing it in writing as a 'regained' experience (implying a quantum leap comparable to Proust's transfiguration of 'lost time' in 'time regained'). Is the writing of desire not ultimately doomed to perpetuate the discontinuity of being which eroticism so yearningly strives to overcome?

The case of Henri Pierre Roché is even more complex as the organising form he searches, morally as well as existentially (and, therefore, plainly engaging the question of writing), frightens him as much as it fascinates him: recreating the moment of desire and its intensity in the face of separation and the passing of time. This precariousness entrusts writing with a function that is as necessary as it is problematic in the construction of the essential self in the face of dislocation and loss. In Henri Pierre Roché and Helen Hessel's written accounts of the passion they shared, the writing of desire and seduction does achieve - albeit fleetingly - a construction

32.If I created a kind of œuvre around his dates - our love seen in the past would place him outside of me - touchable - visible - complete - finished - I would turn away to do something else.'

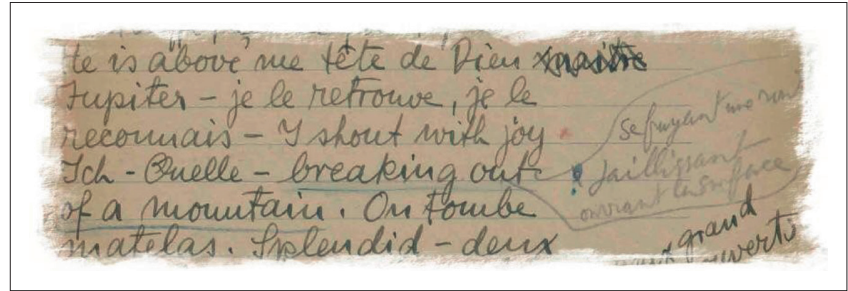

Source: Hessel, H., 1991, Journal d'Helen, André Dimanche, Marseille. [The original copy of Helen Hessel's diary is conserved at the Harry Ransom Centre at the University of Texas at Austin and was consulted with the kind authorization of her son, Stéphane Hessel.]

FIGURE 4: Image from Helen Hessel's diary with annotation by Roché.

of the kind of unity that recalls the cosmogonic Eros - as memory, construction of the self, relational scheme, seal of personal truth and, movingly, as the elevation of sexuality searching to become, and this is very clear in Helen Hessel's (1991:59) writing, a source: 'Je le retrouve - je le reconnais - I shout with joy - Ich - Quelle - jaillissant d'une montagne ${ }^{\prime 33}$ (see Figure 4).

In this polyphonic erotic intrigue, steeped from its conception in literary references, lived in writing and relived in reading, opposites and complementarity, counterpoint and harmony are, as in musical writing, intimately linked. Whereas counterpoint represents a horizontal vision with its organisation of the mechanisms of seduction in distinct melodic lines, harmony holds a vertical image with a progression of chords the final aim of which is the integration of these separate voices. Roché sees this unifying harmony in and through sexual love. A sacred mystery inhabits two bodies united in perfect erotic love and, thus, the source of living water Helen speaks of springs from the body, from the flesh of the lover: 'Il faut connaître, vivre l'amour total, le préserver, le faire vivre et donner sa fleur, qui mène à l'amour universel et mystique, à la fusion en Dieu' ${ }^{34}$ (Journal: 28 February 1944).

In the end, however, the perfect union depends as much on fortitude as on passion and patience. For Henri Pierre Roché, the centre cannot hold. In spite of his profound belief in Eros, he is too cautious, too prudent, too paranoid to accept Helen Hessel's intensity, particularly when the voices of moderate Germaine Bonnard, his long-time mistress, and reasonable Denise Renard, a new damsel in distress, join the choir. Over a period of more than twelve years, after the roaring eruption of their first erotic encounters, his diary bears witness to the measured, intentional demolition of their love:

Opposer des limites verbales à l'amour, c'est vouloir arrêter la mer avec des mots. Oui, je les avais prévenues logiquement, honnêtement. Mais qu'est-ce que cela, si mes mains et mes baisers ont cessé un instant de les prévenir? Elles ont tout oublié $e^{35}$ (Journal: 09 October 1929; Roché 1990)

33.1 rediscover him, I recognize him - I shout with joy - I-Source - breaking out of a mountain.'

34.'One has to know, to live complete love, preserve it, bring it to life, to flower, leading to universal and mystical love and to union with God.'

35.'Opposing verbal limits to love is to stop the ocean with words. Yes, I did warn them, logically, honestly. But what does that help if my hands and my kisses ceased, for a moment, to warn them? They forgot everything.' 
Original Research

\section{Acknowledgements}

\section{Competing interests}

The author declares that she has no financial or personal relationship(s) that may have inappropriately influenced her in writing this article.

\section{References}

Greene, R., 2001, The art of seduction, Profile Books, London. Gusdorf, G., 1991, 'Les Écritures du moi. Lignes de vie I, Odile Jacob, Paris.

Hessel, H., 1991, Journal d'Helen, André Dimanche, Marseille. [The original copy of Helen Hessel's diary is conserved at the Harry Ransom Centre at the University of Texas at Austin and was consulted with the kind authorisation of her son, Stéphane Hessel.]
Kierkegaard, S., 1993, Ou bien ... ou bien... , Robert Laffont, Paris.

Monneyron, F., 1991, 'Séduction de I'illusion, illusion de la séduction', Cahiers internationaux de symbolisme 68-69-70, 163-172. UMH, Mons.

Nietzsche, F. [1886] 1973, Beyond good and evil, Penguin Classics, London.

Reventlow, F. zu, [1912] 1969, Von Paul zu Pedro, Rowohlt Verlag. http://gutenberg. spiegel.de/buch/1419/13

Roché, H., 1990, 'Journal 1898-1959' [unpublished manuscript conserved at the Harry Ransom Centre at the University of Texas at Austin, consulted with the kind authorisation of Jean-Claude Roché in August 1997, May 2004, April 2008, March 2012, October 2013 and June 2014.]

Roché, H., 1990, Carnets 1920-1921, André Dimanche, Marseille.

Stein, G. [1922] 2003, Geography and plays, Dover publications, New York.

Weininger, O. 1904, Geschlecht und Charakter: eine prinzipielle Untersuchung, Braumüller, Vienna, Leipzig.

Weininger, O., 1975, Sexe et caractère, L'Age d'Homme, Lausanne. 